\title{
Use of mild irradiation doses to control pathogenic bacteria on meat trimmings for production of patties aiming at provoking minimal changes in quality attributes
}

\author{
Ma. de la Paz Xavier ${ }^{\mathrm{a}, 1}$, Cecilia Dauber ${ }^{\mathrm{b}, 2}$, Paula Mussio ${ }^{\mathrm{b}, 2}$, Enrique Delgado ${ }^{\mathrm{b}, 2}$, Ana Maquieira ${ }^{\mathrm{b}, 2}$, \\ Alejandra Soria $^{\mathrm{b}, 2}$, Ana Curuchet ${ }^{\mathrm{b}, 2}$, Rosa Márquez ${ }^{\mathrm{b}, 2}$, Carlos Méndez ${ }^{\mathrm{a}, 1}$, Tomás López ${ }^{\mathrm{b}, *}$ \\ a Instituto Nacional de Carnes, Rincón 545, CP 11000 Montevideo, Uruguay \\ ${ }^{\mathrm{b}}$ Laboratorio Tecnológico del Uruguay, Avda. Italia 6101, CP 11500 Montevideo, Uruguay
}

\section{A R T I C L E I N F O}

\section{Article history:}

Received 15 April 2014

Received in revised form 24 June 2014

Accepted 24 June 2014

Available online 4 July 2014

\section{Keywords:}

Trimmings

Irradiation

Listeria monocytogenes

Escherichia coli 0157:H7

Beef patties

Food safety

\begin{abstract}
A B S T R A C T
The objectives of the present work were to assess the use of moderate doses of gamma irradiation ( 2 to $5 \mathrm{kGy}$ ) and to reduce the risk of pathogen presence without altering the quality attributes of bovine trimmings and of patties made of irradiated trimmings. Microbiological indicators (coliforms, Pseudomonas spp and mesophilic aerobic counts), physicochemical indicators ( $\mathrm{pH}$, color and tiobarbituric acid) and sensory changes were evaluated during storage. $5 \mathrm{kGy}$ irradiation doses slightly increased off flavors in patties. Two pathogenic markers (Listeria monocytogenes and Escherichia coli 0157:H7) were inoculated at high or low loads to trimming samples which were subsequently irradiated and lethality curves were obtained. Provided that using irradiation doses $\leq 2.5 \mathrm{kGy}$ are used, reductions of $2 \log \mathrm{CFU} / \mathrm{g}$ of L. monocytogenes and $5 \log \mathrm{CFU} / \mathrm{g}$ of E. coli 0157:H7 are expected. It seems reasonable to suppose that irradiation can be successfully employed to improve the safety of frozen trimmings when initial pathogenic bacteria burdens are not extremely high.
\end{abstract}

(c) 2014 Elsevier Ltd. All rights reserved.

\section{Introduction}

Physicochemical composition of meat provides the conditions for the growth of both microorganisms (banal and pathogenic) and the precursor compounds for the development of aromas and flavors, desirable or undesirable. Physicochemical parameters such as $\mathrm{pH}$, color and lipid oxidation and sensory attributes are gross indicators of meat quality (Brewer, 2004; Lorenz et al., 1983; Shahidi, 1994). Bovine trimmings are the main ingredient of patties produced worldwide. Since this meat results from mechanical disruption of several muscles, assessing microbiological markers becomes mandatory and this is used as a trade standard. In particular, mechanically recovered meat, ground meat and meat mixes containing spices, shall all comply with specifications of microbiological markers such as total mesophilic counts, Escherichia coli counts and absence of pathogenic strains. Among pathogens Listeria monocytogenes and E. coli $0157:$ H7 need to be seriously taken into account.

\footnotetext{
* Corresponding author. Tel.: +598 26013724

E-mail addresses: cmendez@inac.gub.uy (C. Méndez), tlopez@latu.org.uy (T. López).

1 Tel.: + 59829160430

2 Tel.: + 59826013724
}

There are several types of E. coli strains that may cause gastrointestinal illness in humans. Vero-toxin producing or Shiga-toxin producing E. coli (VTEC or STEC, respectively) have emerged as important food-borne pathogens, especially 0157, 026, 0103, 0111, 0145, 045, 091, 0113, 0121 and 0128 serogroups (Momtaz, Farzan, Rahimi, Safarpoor Dehkordi, \& Souod, 2012). The pathogenic capacity of STEC resides in a number of virulence factors, including Shiga toxins (stx 1 and stx2), protein intimin (eae) and enterohemolysin (ehly) (Law, 2000). The Shiga toxins produced may cause from diarrhea to hemorrhagic colitis, which can progress into hemolytic uremic syndrome (HUS), (EFSA, 2011). Cattle is a reservoir of zoonotic STEC which are transmitted to humans through meat and meat products (Caprioli, Morabito, Brugere, \& Oswald, 2005; Momtaz, Dehkordi, Rahimi, Ezadi, \& Arab, 2013). Different incidences of STEC meat contamination have been reported from various sites in the world, ranging from 2 to 50\%, with strain 0157:H7 the most frequently reported (Ojo et al., 2010).

Outbreaks from L. monocytogenes are not common compared with those caused by other pathogens like Salmonella spp. However, they receive considerable attention because they usually cause serious symptoms cases and even deaths. In 2010, 1601 confirmed cases of listeriosis were reported in Europe, 17\% of which ended fatally (EFSA, 2012). USA authorities reported an incidence of 0.3 listeriosis cases per 100,000 
populations during 2010 with a high mortality rate of $13 \%$ (CDC, 2011). L. monocytogenes is ubiquitous in the environment. Its ability to proliferate at low temperatures, $\mathrm{pH}$ values around 6 and water activities above 0.97 , such as those of many meat products and ingredients, allow many strains of $L$. monocytogenes to grow during refrigerated storage, showing high prevalence in processing plants (Talon et al., 2007) and domestic refrigerators (EFSA, 2007; Hereu, Dalgaard, Garriga, Aymerich, \& Bover-Cid, 2012; ILSI, 2005; Jofré, Aymerich, Grèbol, \& Garriga, 2009; Warriner \& Namvar, 2009). Its presence in foods is often caused by mistakes of workers at manufacturing plants that are found to be typically out of compliance with existing regulations; the outbreaks have major economic consequences, especially if the products affect international trade (Todd \& Notermans, 2011).

Irradiation may be applied to packaged products extending their shelf-life and improving their microbiological safety with minimal effects on their chemical composition, and on their nutritional and sensory properties. The effects of ionizing radiation on living organisms depend on the total dose absorbed, the rate of absorption, and the environmental conditions (mainly temperature and gas atmosphere) during irradiation (Brewer, 2004). Food spoilage microorganisms are generally very susceptible to irradiation; a $90 \%$ reduction of most vegetative cells can be accomplished with 1.0-1.5 kGy (ICGFI, 1996; Olson, 1998a, 1998b; Thayer, Boyd, Fox, Lakritz, \& Hampson, 1995). Irradiation followed to storage at refrigerating temperatures was found to be a very effective way to reduce initial microbial loads in ground beef, improve safety and extend shelf life without affecting sensory quality. Irradiation dose was directly related to the elimination of pathogens such as L. monocytogenes and E. coli 0157:H7 (Fu, Sebranek, \& Murano, 1995).

When biological materials are exposed to irradiation energy, the atoms or molecules eject electrons producing ions and free radicals. The electron-deficient carbon-carbon double bonds of unsaturated fatty acids and carbonyl groups (fatty acids and amino acids) are particularly susceptible to free radical attack. This is why even at low doses, irradiation can initiate or promote lipid oxidation resulting in undesirable off-odors and flavors (Lescano, Narvaiz, Kairiyama, \& Kaupert, 1991; Thakur \& Singh, 1994). Temperature may determine the ratio and kind of radiolytic products generated due to irradiation. Reducing the temperature during irradiation reduces the effects on odor/flavor and color. The effect of irradiation on volatile compounds among muscle types within species, though beef meat has proven to show similar oxidation indexes for both, high or low fat contents.

Irradiating fresh beef at doses sufficient to extend shelf life and reduce pathogen load may result in rapid development of brown, green or, in some cases, bright red oxymyoglobin-like pigments. Irradiation produces a variety of color changes which are related to the myoglobin concentration, the state of myoglobin prior to irradiation, $\mathrm{pH}$, water activity, presence of reducing equivalents, temperature and gas atmosphere during irradiation. Studies reporting color changes in irradiated raw meat differ significantly with animal species and among muscles within animal species (Ahn, Olson, Jo, et al., 1998; Brewer, 2004). The effect on $\mathrm{L}^{*}$ and $\mathrm{a}^{*}$ values of different meats varies widely whereas there seems to be an agreement in the decrease of $b$ values due to irradiation (Montgomery, Parrish, \& Olson, 2000; Murano, Murano, \& Olson, 1998; Nam \& Ahn, 2003). Elevated doses (above those permitted for food irradiation) of $50 \mathrm{kGy}$ can completely destroy myoglobin. It should be mentioned that for pathogen reduction, a maximum of $4.5 \mathrm{kGy}$ is permitted for uncooked, chilled red meat and $7 \mathrm{kGy}$ is permitted for uncooked, frozen meat (FDA, 2012). The quality changes induced by irradiation can increase with storage time.

The objectives of the present work were to assess the use of moderate doses of irradiation as a tool to reduce (or mitigate) pathogen presence without altering the quality attributes of bovine trimmings and patties made of irradiated trimmings, covering: microbiological indicators during 30 days of storage (coliforms, pseudomonas and mesophilic aerobics counts); physicochemical indicators ( $\mathrm{pH}$, color and oxidation); sensory changes during a 180 day storage period at freezing temperatures and pathogenic markers (counts of L. monocytogenes and E. coli 0157:H7) in inoculated samples.

\section{Materials and methods}

\subsection{Obtaining of beef trimmings}

Beef trimmings (20\% fat) were obtained from a local slaughter house. Fresh trimmings ( 0 days age) from grass-fed animals were divided at deboning room in $2.5 \mathrm{~kg}$ and $200 \mathrm{~g}$ portions for patty manufacture and trimming analysis, respectively. Trimmings for microbiological analysis were placed into sterile bags (Whirl Pak ${ }^{\circledR}$ ) while trimmings for other analyses and for patty manufacture were placed into polyethylene bags (oxygen permeability: $1200 \mathrm{~cm}^{3} / \mathrm{m}^{2} .24 \mathrm{~h}$ at $23{ }^{\circ} \mathrm{C} / \mathrm{HR}=0$ as informed by supplier). Bags were transferred under refrigerating conditions to the pilot plant where they were stored at $(-18 \pm 2){ }^{\circ} \mathrm{C}$ or $(2 \pm$ 2) ${ }^{\circ} \mathrm{C}$ (see Fig. 1).

\subsection{Irradiation method}

After $24 \mathrm{~h}$ of storage, bags were transferred under frozen or chilled conditions to the irradiation unit (Laboratorio Tecnológico del Uruguay, LATU, Montevideo, Uruguay). Samples were irradiated frozen or chilled. Irradiated and non-irradiated trimmings bags were stored at $(2 \pm 2)^{\circ} \mathrm{C}$ for $24 \mathrm{~h}$ before being analyzed or destined to patty manufacture. Samples destined to evaluation after 30 days were stored at $(-18 \pm 2){ }^{\circ} \mathrm{C}$ after irradiation. Irradiation was carried out at room temperature under a Cobalt-60 radiation source (Modular Equipment EMI-9, dry shield, Buenos Aires, Argentina). The process was performed in $23 \mathrm{~L}$ cylindrical aluminum containers at a mean dose rate of $20 \mathrm{kGy} / \mathrm{h}$. Measurement of the irradiation absorbed dose was performed with alanine dose-meters (ISO, 2004) using an EPR spectrometer (MS400, Miniscope, Magnettech, Berlin, Germany) and PMMA Ambar (ISO, 2002), using a spectrophotometer Shimadzu UV1800 (Kyoto, Japan).

\subsection{Bacterial cultures and inoculation of samples}

Reference strains of L. monocytogenes (ATCC 19111) and nonpathogenic E. coli 0157:H7 (NCTC 12900) were used to artificially contaminate the samples to be irradiated. The cultures were kept frozen at $(-80 \pm 2)^{\circ} \mathrm{C}$ and they were activated by transferring an aliquot of the stock into nutrient broth-NB (Oxoid, Hampshire, United Kingdom) and incubating overnight at $37^{\circ} \mathrm{C}$ and $100 \mathrm{rpm}$. For the preparation of the inoculum suspension (IS) successive dilutions were made in phosphate water to obtain the expected concentration for each stage of the study. The actual load of the IS was confirmed by making counts of the suspension with the automatic enumeration methodology TEMPO TVC (BioMérieux, Marcy-l'Étoile, France).

\subsection{Microbiological analysis}

Total aerobic counts were performed on Plate Count Agar-PCA (Oxoid, Hampshire, United Kingdom) and incubated at $(35 \pm 1)^{\circ} \mathrm{C}$ for 2 days. For Coliform enumerations, Most Probable Number methodology with Lauryl Tryptose Broth (Oxoid, Hampshire, United Kingdom) was used. The inoculated broth tubes were incubated at $(35 \pm 1)^{\circ} \mathrm{C}$ for ( $48 \pm 2$ ) h. Confirmation of positive tubes was performed using EC broth (Oxoid, Hampshire, United Kingdom) and Tryptone Water (Oxoid, Hampshire, United Kingdom). To enumerate Pseudomonas spp., Pseudomonas Agar Base (Oxoid, Hampshire, United Kingdom) supplemented with CFC (10 mg/L Cetrimide, $10 \mathrm{mg} / \mathrm{L}$ Fucidin, $50 \mathrm{mg} / \mathrm{L}$ Cephaloridine) was used and incubated at $25^{\circ} \mathrm{C}$ for $(48 \pm 2) \mathrm{h}$.

L. monocytogenes. The inoculated samples were hydrated with $1125 \mathrm{~mL}$ of Half Fraser Broth (HFB) (Fraser broth base with Half Fraser selective supplement SR0166, Oxoid, Hampshire, United Kingdom), and incubated at $(30 \pm 1){ }^{\circ} \mathrm{C}$ for $(24 \pm 2) \mathrm{h}$. The detection was done 


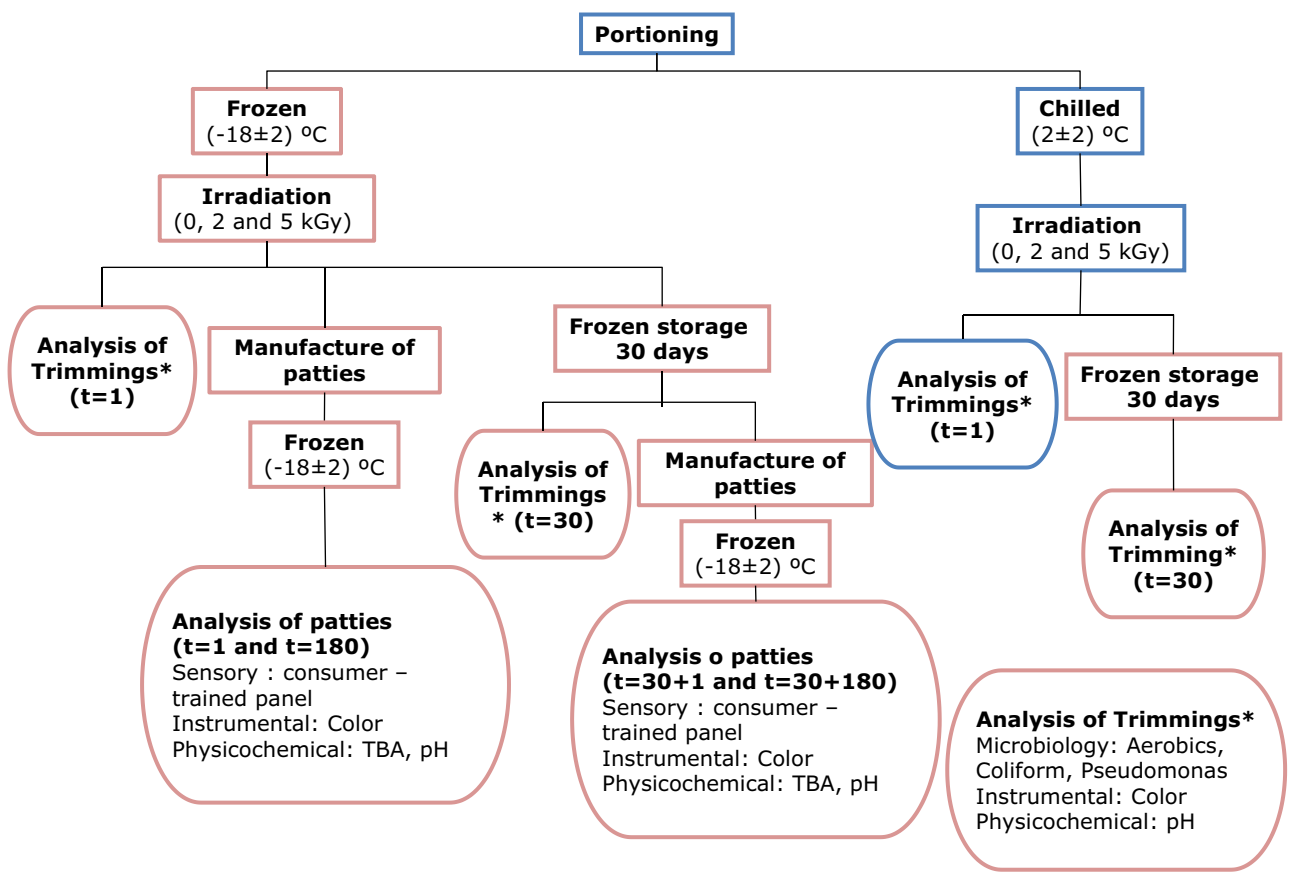

Fig. 1. Schematic procedure of sample treatments for commercial quality study.

by PCR and by the traditional ISO method for Listeria (ISO, 1996). When PCR was used, $5 \mathrm{~mL}$ of the Half Fraser Broth (HFB) was transferred into $45 \mathrm{~mL}$ of MOPS-BLEB Broth (Oxoid, Hampshire, United Kingdom) and incubated at $(35 \pm 1){ }^{\circ} \mathrm{C}$ for $(24 \pm 2) \mathrm{h}$. Detection of $L$. monocytogenes was done by PCR, using the "BAX® System PCR Assay for L. monocytogenes" (Dupont, Wilmington, Delware, USA). In the cases when the results were "weak positive" the grown MOPS were streaked on Agar Listeria Ottavani \& Agosti-ALOA (Oxoid, Hampshire, United Kingdom) and incubated at $(37 \pm 1){ }^{\circ} \mathrm{C}$ for $(48 \pm 2)$ h to confirm the results. To follow the traditional methodology, $5 \mathrm{~mL}$ of HFB was transferred to $45 \mathrm{~mL}$ Fraser Broth-FB (Fraser broth base with Fraser selective supplement SR0156, Oxoid, Hampshire, United Kingdom) and incubated for (48 \pm 2$)$ h at $(35 \pm 1){ }^{\circ} \mathrm{C}$. The HFB was re-incubated at $(30 \pm 1){ }^{\circ} \mathrm{C}$ for 1 more day. Both broths, HFB and FB, were streaked on Palcam Agar (Oxoid, Hampshire, United Kingdom) and ALOA and incubated for $(48 \pm 2)$ h at (37 $\pm 1)^{\circ} \mathrm{C}$.

The detection of E. coli 0157:H7 was done using PCR "BAX® System PCR Assay for Screening E. coli 0157:H7 MP” (Dupont, Wilmington, Delware, USA). The enrichment was made in Tryptic Soy Broth, modified with $8 \mathrm{mg} / \mathrm{L}$ of novobiocine and acid digest of casein-mTSB (Acumedia, Neogen, USA) incubated at $(41 \pm 1){ }^{\circ} \mathrm{C}$ for $16-20 \mathrm{~h}$. To confirm "weak positive" results, m-TSB was immunoconcentrated for $E$. coli 0157:H7 using VIDAS ${ }^{\circledR}$ Immuno-Concentration E. coli 0157-ICE (BioMérieux, Marcy-l'Étoile, France) and streaked on CHROMagar ${ }^{\mathrm{TM}}$ O157 (CHROMagar, Paris, France) or Cefixime Tellurite Sorbitol.

\subsection{Physicochemical and instrumental analysis}

$\mathrm{pH}$ measurements were made with a $\mathrm{pH}$ Meter (SevenMultiTM, METTLER TOLEDO, Greifensee, Switzerland) equipped with a temperature sensor and a combined penetration electrode previously calibrated with $\mathrm{pH} 4.00$ and 7.00 buffer solutions. Five samples of each condition were measured and averaged.

To determine tiobarbituric acid (TBA), samples were processed in a RETSCH Grindomix GM200 knife mill (Haan, Germany) at range mode with $600 \mathrm{rpm}$ for $10 \mathrm{~s}$ for 3 times to prevent overheating. Prior to TBA analysis, fat was removed from the samples according to the Folch method. TBA analysis was performed according to the AOCS (2009) -TBA Value Direct Method. Values were calculated in mg of malonaldehyde/kg meat.

Color analysis of beef trimmings and patties was performed on a Hunterlab LabScan ${ }^{\circledR}$ XE Colorimeter (Hunter Associates Laboratory Inc., Reston, Virginia, USA) with illuminant A/10 and open cell of $44 \mathrm{~mm}$. Parameters L* (lightness), a* (redness) and b* (yellowness) were obtained and the saturation index was calculated according to AMSA (2012). For beef trimmings, 5 samples of each condition were measured 3 times each, while for patties, 3 samples were measured on both sides 3 times each.

\subsection{Sensory evaluation.}

Sensory properties of cooked patties were evaluated by a trained panel and the acceptability of samples was evaluated by consumers. Both analyses were carried out in a standardized test room (ISO 8589:2007). Patties were grilled for $4-6$ min until reaching $70{ }^{\circ} \mathrm{C}$ at the center of the piece. Temperature was monitored with a digital thermometer Fluke 54 II (Fluke Corporation, Everett, Washington, USA). The samples were cut into quarters, wrapped in aluminum paper, coded with three digit random numbers and kept warm until they were served. Sample presentation order was randomized to prevent any flavor carryover effects. Mineral water was provided for mouth-rinsing. A nine-member trained descriptive attribute panel was screened, selected, and trained according to AMSA (1995). The assessors evaluated aroma intensity, off-aroma, flavor intensity, off-flavor, tenderness (initial), tenderness (final impression) and initial juiciness. They used a 0-10 unstructured line scale for all attributes. 35 to 50 consumers between 18 and 65 years old, evaluated the overall acceptability of the three samples in one session using a 9-point hedonic scale ( $1=$ "dislike extremely", 9 = "like extremely").

\subsection{Meat quality attributes}

Quality attributes of trimmings, irradiated at freezing $\left(-18 \pm 2{ }^{\circ} \mathrm{C}\right)$ or chilling $\left(2 \pm 2{ }^{\circ} \mathrm{C}\right)$ temperatures, and patties made of irradiated 


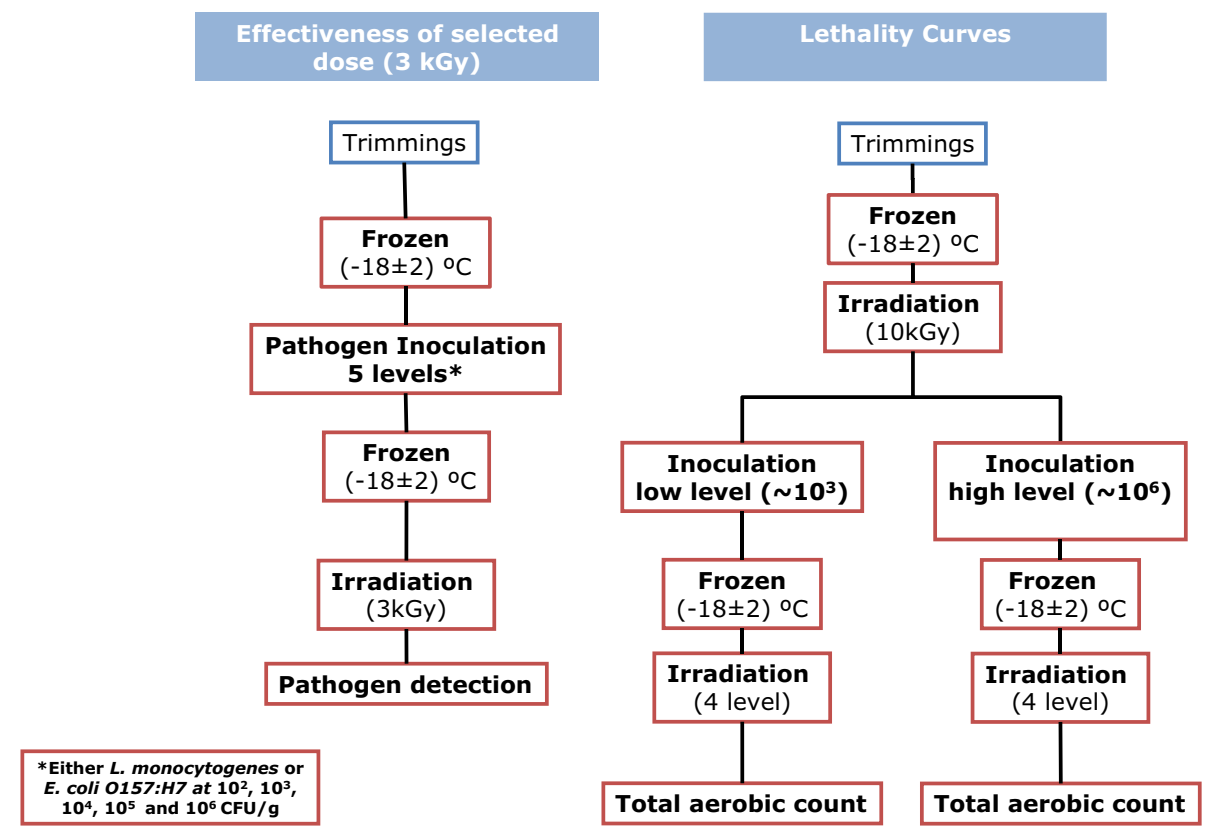

Fig. 2. Schematic procedure of sample treatment for determination of irradiation effects on pathogenic cells.

trimmings were assessed on microbiological, physicochemical and sensory analyses according to Section 2.7.3. These results were used to define the irradiation dose capable of maintaining the quality attributes of the product unchanged, termed for practical purpose "selected dose" from now on.

\subsubsection{Irradiation of samples for quality attributes assays}

Trimmings ( $2.5 \mathrm{~kg}$ and $200 \mathrm{~g}$ bags) were irradiated at target doses of $2 \mathrm{kGy}$ (D1) and $5 \mathrm{kGy}$ (D2) according to 2.2. Dose-meters' actual range doses recorded were [2.2 to 3.1] and [4.6 to 5.5] kGy for $2.5 \mathrm{~kg}$ bags and [2.2 to 2.4] and [ 4.6 to 5.1] kGy for $200 \mathrm{~g}$ bags. Non-irradiated ( $\mathrm{Ni}, 0 \mathrm{kGy}$ ) samples were used as control.

\subsubsection{Manufacture of patties.}

For each irradiation dose (Ni, D1 and D2), batches of $10 \mathrm{~kg}$ (four $2.5 \mathrm{~kg}$ bags) frozen beef trimmings were fine ground through a $3 \mathrm{~mm}$ hole plate using a Laska angle grinder (Traun, Austria). Ground beef was mixed for 2 min with salt $(0.75 \%)$, citric acid (0.2\%) and ascorbic acid $(0.7 \%)$ in a Laska mixer (Traun, Austria) equipped with Z-shaped mixing arms. Patties of $80 \mathrm{~g}$ were manufactured in a Hollymatic Supermodel 54 patty machine (Hollymatic Corporation, Illinois, USA) and placed in perforated stainless steel trays for freezing in a chamber with forced air flow. Packaging was carried out $24 \mathrm{~h}$ after preparation using polypropylene bags heat sealed with a Hualian FRT-800 sealer (Hualian Machinery Group Co. Wenzhou, Zhejiang, China). They were immediately placed into cardboard boxes and stored at $(-18 \pm 2)^{\circ} \mathrm{C}$. Another series of patties manufacture were performed with trimmings aged 30 days at $(-18 \pm 2)^{\circ} \mathrm{C}$. The patties were stored up to 180 days from its elaboration.

\subsubsection{Analysis}

Microbiological, $\mathrm{pH}$ and instrumental color analyses were carried out on frozen and chilled trimmings irradiated at Ni, D1 or D2 on samples stored 1 and 30 days. Instrumental color, TBA and sensory analyses were carried out on patties manufactured from frozen trimmings irradiated at Ni, D1 or D2 immediately after elaboration and after 180 days of frozen storage. Analyses were performed according to Sections 2.4, 2.5 and 2.6.

\subsection{Effects of irradiation on pathogenic cells}

The effectiveness of the selected irradiation dose of $3 \mathrm{kGy}$ (mainly based on sensory evaluation, since changes in the other parameters studied were not significant) was studied on samples independently inoculated with both pathogenic strains at different levels (see Section 2.8.1). Lethality curves were obtained using two inoculum levels (low and high; see Section 2.8.1) and four irradiation doses chosen based on the data collected in the previous experiments (see Fig. 2).

\subsubsection{Inoculation of samples}

Trimmings were divided into sterile sampling bags containing $125 \mathrm{~g}$ (qualitative stages) or $11 \mathrm{~g}$ (quantitative stages) and frozen. $100 \mu \mathrm{L}$ of the IS was inoculated into the meat sample and thoroughly mixed. The inoculated sample was then sealed and kept chilled for $1 \mathrm{~h}$ before being frozen again. Concentrations of $10^{2}, 10^{3}, 10^{4}, 10^{5}$ and $10^{6} \mathrm{cfu} / \mathrm{g}$

Table 1

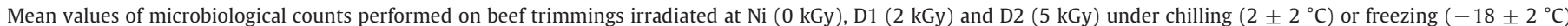
temperatures $(n=6)$. Non irradiated samples were used as controls. Within rows, means values with common letters $(\mathrm{a}, \mathrm{b})$ do not significantly differ $(P>0.05)$.

\begin{tabular}{|c|c|c|c|c|c|c|c|c|c|c|c|c|}
\hline & \multicolumn{4}{|l|}{$\mathrm{Ni}$} & \multicolumn{4}{|l|}{ D1 } & \multicolumn{4}{|l|}{ D2 } \\
\hline & \multicolumn{2}{|c|}{ Chilled } & \multicolumn{2}{|c|}{ Frozen } & \multicolumn{2}{|c|}{ Chilled } & \multicolumn{2}{|c|}{ Frozen } & \multicolumn{2}{|c|}{ Chilled } & \multicolumn{2}{|c|}{ Frozen } \\
\hline & $1 \mathrm{~d}$ & $30 \mathrm{~d}$ & $1 \mathrm{~d}$ & $30 \mathrm{~d}$ & $1 \mathrm{~d}$ & $30 \mathrm{~d}$ & $1 \mathrm{~d}$ & $30 \mathrm{~d}$ & $1 \mathrm{~d}$ & $30 \mathrm{~d}$ & $1 \mathrm{~d}$ & $30 \mathrm{~d}$ \\
\hline Total aerobic $\log (\mathrm{cfu} / \mathrm{g})$ & $2.68^{\mathrm{a}}$ & $2.54^{\mathrm{a}}$ & $2.68^{\mathrm{a}}$ & $2.72^{\mathrm{a}}$ & $0.45^{\mathrm{b}}$ & $<1$ & $<1$ & $<1$ & $<1$ & $<1$ & $<1$ & $<1$ \\
\hline Pseudomonas log (cfu/g) & $1.82^{\mathrm{a}}$ & $1.18^{\mathrm{b}}$ & $2.03^{\mathrm{a}}$ & $1.11^{\mathrm{b}}$ & $<1$ & $<1$ & $<1$ & $<1$ & $<1$ & $<1$ & $<1$ & $<1$ \\
\hline Coliforms (NMP/g) & $<3$ & $<3$ & $<3$ & $<3$ & $<3$ & $<3$ & $<3$ & $<3$ & $<3$ & $<3$ & $<3$ & $<3$ \\
\hline E. coli $(\mathrm{NMP} / \mathrm{g})$ & $<3$ & $<3$ & $<3$ & $<3$ & $<3$ & $<3$ & $<3$ & $<3$ & $<3$ & $<3$ & $<3$ & $<3$ \\
\hline
\end{tabular}


Table 2

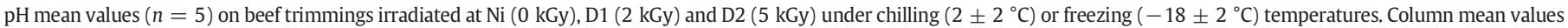
with the same superscript $\left({ }^{\mathrm{a}}\right)$ do not differ $(P>0.05)$.

\begin{tabular}{|c|c|c|c|c|c|c|}
\hline \multicolumn{3}{|c|}{ Irradiation dose (kGy) } & \multicolumn{2}{|c|}{ Storage time (days) } & \multicolumn{2}{|c|}{ Irradiation temperature } \\
\hline $\mathrm{Ni}$ & D1 & $\mathrm{D} 2$ & 1 & 30 & Chilled & Frozen \\
\hline $5.62^{\mathrm{a}}$ & $5.61^{a}$ & $5.61^{\mathrm{a}}$ & $5.60^{\mathrm{a}}$ & $5.62^{\mathrm{a}}$ & $5.63^{\mathrm{a}}$ & $5.59^{\mathrm{a}}$ \\
\hline
\end{tabular}

of L. monocytogenes and of E. coli 0157:H7 were used to study selected dose effectiveness.

Lethality curves were studied for two levels of pathogens concentrations: $10^{3} \mathrm{cfu} / \mathrm{g}$ (low concentration) and $10^{6} \mathrm{cfu} / \mathrm{g}$ (high concentration). Trimmings were previously irradiated at $10 \mathrm{kGy}$ to eliminate interference of microorganisms present in the samples.

\subsubsection{Irradiation of inoculated samples}

As stated before, $3 \mathrm{kGy}$ was used as target for selected dose taking into account results from sensory trials (absence of off-odors/flavors and highest limit of absorbed dose in D1, see Section 2.7.1). The actual doses absorbed were $3.3 \mathrm{kGy}$ for L. monocytogenes and $3.1 \mathrm{kGy}$ for E. coli. To obtain lethality curves, the following target doses were selected: $0.4 ; 0.7 ; 1$ and $0.5 ; 1 ; 1.5 \mathrm{kGy}$ to low and high E. coli $0157: \mathrm{H7}$ concentrations, respectively and $0.5 ; 1 ; 1.5 \mathrm{kGy}$ and $1 ; 2 ; 2.5 \mathrm{kGy}$ to low and high $L$. monocytogenes concentrations, respectively. Irradiation process was carried out as explained in Section 2.2.

Pathogen detection was used to determine the effectiveness of the selected dose and total aerobic counts (Section 2.4) were performed for lethality curve construction because it was assumed that only inoculated pathogen cells represent the majority of the bacteria population in inoculated samples (see Section 2.8.1).

\subsubsection{Statistical analysis}

Each experiment was performed at least two separate times with three samples analyzed in each replicate. Analyses of variance (ANOVA) was performed over instrumental color and pH data using the statistical software Infostat/L version 2013 (Universidad Nacional de Córdoba, Argentina). Microbiological counts were converted to log $\mathrm{cfu} / \mathrm{g}$. Dose, storage time and temperature of irradiation and storage were considered as sources of variation. Data of sensory analysis and microbiology counts were analyzed by ANOVA using XLSTAT Version 2011 (Addinsoft 1995-2010, France). A post-hoc Tukey test was used to obtain paired comparisons among sample means. Level of significance was set to 0.05 .

\section{Results and discussion}

\subsection{Meat quality attributes}

Table 1 shows that for D1 irradiation dose ( $2 \mathrm{kGy}$ ), total aerobic counts of $3 \log (\mathrm{cfu} / \mathrm{g})$ in trimmings were reduced by at least $1.5 \log$ orders. This result agrees with previous findings of Chouliara et al. (2006) who reported that frozen trimmings irradiated at $2 \mathrm{kGy}$ under Co-60 source reduced total aerobic counts of $6.1 \mathrm{log}(\mathrm{cfu} / \mathrm{g})$ in $1.6 \log$ orders. Karadag and Günes (2007) found that for Pseudomonas spp, the same dose (2.2 kGy) caused a reduction of at least 1 log order for an initial load of nearly $2 \log (\mathrm{cfu} / \mathrm{g})$. The temperature of the different irradiation treatments (chilling vs freezing) did not significantly affect the results. Overall, irradiation at D1 dose had a significant improvement on hygienic quality which was practically similar to that caused by an irradiation dose of $5 \mathrm{kGy}$. For both irradiation doses, reductions obtained on day 1 after treatment were preserved during a 30 day storage period at freezing temperatures. This implies that irradiation may provide an alternative capable of decreasing the microbial load of meat products. Most spoilage microorganisms in meat are gram negative with Pseudomonas spp. predominant for aerobic storage at chilling temperatures.

\subsection{1. $\mathrm{pH}$}

$\mathrm{pH}$ results of all samples tested varied between 5.56 and 5.68 (Table 2). $\mathrm{pH}$ values did not show significant differences $(P>0.05)$ for: irradiation dose, temperature and storage time. These results agree with those reported by Fu et al. (1995), who did not observe changes in the $\mathrm{pH}$ of fillets irradiated with 0.6 and $1.5 \mathrm{kGy}$, on 0 and 7 days of storage. According to Brewer (2004), irradiation can only produce very small changes in the $\mathrm{pH}$ of meat.

\subsubsection{Lipid oxidation}

TBA values of patties made of trimmings irradiated at both D1 and D2, and stored 1 and 30 days did not significantly differ $(P>0.05$; data not shown). Whereas Ni samples of trial 1 showed significant

Table 3

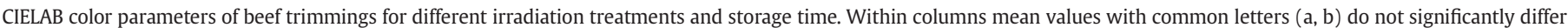
$(P>0.05)$. ns, not statistically significant, ${ }^{*} P<0.05,{ }^{* *} P<0.01,{ }^{* * *} P<0.001$.

\begin{tabular}{|c|c|c|c|c|}
\hline & $\mathrm{L}^{*}$ & $a^{*}$ & $b^{*}$ & Saturation index \\
\hline \multicolumn{5}{|c|}{$\begin{array}{l}\text { Effect of irradiation dose } \\
\quad \text { (Overall irradiation temperature and storage time) }\end{array}$} \\
\hline $\mathrm{Ni}(0 \mathrm{kGy})$ & $34.89^{\mathrm{a}}$ & $26.03^{\mathrm{a}}$ & $19.47^{\mathrm{a}}$ & $32.54^{\mathrm{a}}$ \\
\hline D1 (2 kGy) & $34.07^{\mathrm{a}}$ & $23.20^{\mathrm{b}}$ & $17.54^{\mathrm{b}}$ & $29.12^{\mathrm{b}}$ \\
\hline D2 (5 kGy) & $34.66^{\mathrm{a}}$ & $23.42^{\mathrm{b}}$ & $17.66^{\mathrm{b}}$ & $29.38^{\mathrm{b}}$ \\
\hline Statistical significance & ns & & & \\
\hline \multicolumn{5}{|c|}{$\begin{array}{l}\text { Effect of storage time } \\
\text { (Overall irradiation dose and irradiation temperature) }\end{array}$} \\
\hline 1 day storage & $36.05^{\mathrm{a}}$ & $24.66^{\mathrm{a}}$ & $18.60^{\mathrm{a}}$ & $30.92^{\mathrm{a}}$ \\
\hline 30 day storage & $33.04^{\mathrm{b}}$ & $23.77^{\mathrm{a}}$ & $17.85^{\mathrm{a}}$ & $29.77^{\mathrm{b}}$ \\
\hline Statistical significance & $* * *$ & & ns & \\
\hline \multicolumn{5}{|c|}{$\begin{array}{l}\text { Effect of irradiation temperature } \\
\quad \text { (Overall irradiation dose and storage time) }\end{array}$} \\
\hline $2{ }^{\circ} \mathrm{C}$ & $34.56^{\mathrm{a}}$ & $22.93^{\mathrm{a}}$ & $17.56^{\mathrm{a}}$ & $28.93^{\mathrm{a}}$ \\
\hline$-18{ }^{\circ} \mathrm{C}$ & $34.53^{\mathrm{a}}$ & $25.50^{\mathrm{b}}$ & $18.89^{b}$ & $31.76^{\mathrm{b}}$ \\
\hline Statistical significance & ns & $* * *$ & & $* * *$ \\
\hline
\end{tabular}


Table 4

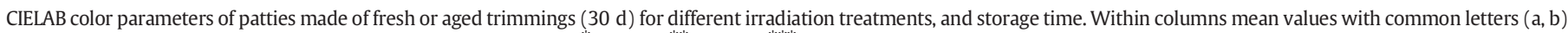
do not significantly differ $(P>0.05)$. ns, not statistically significant, ${ }^{*} P<0.05,{ }^{* *} \mathrm{P}<0.01,{ }^{* * *} P<0.001$.

\begin{tabular}{|c|c|c|c|c|}
\hline & $\mathrm{L}^{*}$ & $a^{*}$ & $\mathrm{~b}^{*}$ & Saturation index \\
\hline \multicolumn{5}{|l|}{ Effect of irradiation dose } \\
\hline $\mathrm{Ni}(0 \mathrm{kGy})$ & $46.35^{\mathrm{a}}$ & $17.00^{\mathrm{a}}$ & $18.33^{\mathrm{a}}$ & $25.05^{\mathrm{a}}$ \\
\hline D1 (2 kGy) & $45.49^{\mathrm{a}}$ & $17.15^{\mathrm{a}}$ & $18.14^{\mathrm{a}}$ & $24.99^{\mathrm{a}}$ \\
\hline D2 (5 kGy) & $46.19^{\mathrm{a}}$ & $18.36^{\mathrm{a}}$ & $18.98^{\mathrm{a}}$ & $26.44^{\mathrm{a}}$ \\
\hline Statistical significance & ns & ns & ns & ns \\
\hline \multicolumn{5}{|c|}{$\begin{array}{l}\text { Effect of trimmings age before patty production } \\
\text { (Overall irradiation dose and storage time) }\end{array}$} \\
\hline 1 day storage & $44.86^{\mathrm{a}}$ & $16.70^{\mathrm{a}}$ & $18.07^{\mathrm{a}}$ & $24.63^{\mathrm{a}}$ \\
\hline 30 day storage & $47.15^{\mathrm{b}}$ & $18.31^{\mathrm{b}}$ & $18.90^{\mathrm{b}}$ & $26.35^{\mathrm{b}}$ \\
\hline Statistical significance & $* * *$ & $* *$ & & \\
\hline \multicolumn{5}{|l|}{ Effect of storage time } \\
\hline 1 day & $46.64^{\mathrm{a}}$ & $18.28^{\mathrm{a}}$ & $18.65^{\mathrm{a}}$ & $26.16^{\mathrm{a}}$ \\
\hline 180 days & $45.37^{\mathrm{b}}$ & $16.73^{\mathrm{b}}$ & $18.31^{\mathrm{a}}$ & $24.82^{\mathrm{b}}$ \\
\hline Statistical significance & $* *$ & $* *$ & $\mathrm{~ns}$ & \\
\hline
\end{tabular}

differences $(P<0.05)$ between samples stored 1 and 30 days, Ni samples of trial 2 did not show those differences. Lipid stability could be due to the fact that trimmings used were from grass-fed animals. Brito (2005) reported that trimmings from grass-fed animals usually contains high levels of vitamin E (a well-known antioxidant compound) that might help to prevent increases in fat oxidation due to irradiation processing. Furthermore, since ascorbic acid was used as an ingredient for patty formulation at $0.7 \%$, the compound could be responsible of preventing oxidation increases. Ahn and Nam (2004) did not report significant differences on TBA values of ground beef with ascorbic acid at $0.1 \%$ irradiated at $2.5 \mathrm{kGy}$ along 7 days, while control samples (without ascorbic acid) did show an increase.

\subsubsection{Color}

Non irradiated (Ni) samples presented higher $\mathrm{a}^{*}$ and $\mathrm{b}^{*}$ values than the irradiated ones (Table 3), but there was no significant difference between the two doses (D1 and D2). Visual evaluation also suggested that irradiated samples were less red. Nanke, Sebranek, and Olson (1999) reported, as well, lower $\mathrm{a}^{*}$ and $\mathrm{b}^{*}$ values in beef irradiated with doses ranging from 1.5 to $10.5 \mathrm{kGy}$ compared to control samples nonirradiated. According to Lycometros and Brown (1973), who studied pigment behavior on model systems, changing from oxymyoglobin to metmyoglobin at the surface could explain the lower $a^{*}$ values on the exterior surface of irradiated beef. Obtained values of $a^{*}$ and $b^{*}$ were affected by the temperature of the samples at the moment of the irradiation process, and they were significantly lower in chilled samples than in the frozen ones. For non-irradiated samples, this difference was not significant. In agreement with Brewer (2004), this suggests that chilled irradiated samples experience more changes than frozen irradiated samples. Reducing the temperature during the irradiation process reduces the effects on odor, flavor and color. Temperature may determine which

\section{Table 5}

Odd flavor intensity mean rates for patties made of fresh (1 d) and aged (30 d) trimmings. Within columns, treatment means with common letters (a-b) are not significantly different $(P>0.05)$. Within rows, treatment means with common letters $(x-y)$ are not significantly different $(P>0.05)$.

\begin{tabular}{lllll}
\hline & \multicolumn{2}{l}{ Off flavor intensity (0 to 10) } \\
\cline { 2 - 5 } & $\begin{array}{l}\text { Patties made of } 1 \mathrm{~d} \\
\text { trimmings }\end{array}$ & \multicolumn{2}{l}{$\begin{array}{l}\text { Patties made of } 30 \mathrm{~d} \\
\text { trimmings }\end{array}$} \\
\hline Dose & $1 \mathrm{~d}$ & $180 \mathrm{~d}$ & $1 \mathrm{~d}$ & $180 \mathrm{~d}$ \\
$\mathrm{Ni}$ & $0.3^{\mathrm{a}, \mathrm{x}}$ & $1.5^{\mathrm{a}, \mathrm{y}}$ & $0.1^{\mathrm{a}, \mathrm{x}}$ & $0.2^{\mathrm{a}, \mathrm{x}}$ \\
$\mathrm{D} 1$ & $0.7^{\mathrm{a}, \mathrm{b}, \mathrm{x}}$ & $1.3^{\mathrm{a}, \mathrm{x}}$ & $0.7^{\mathrm{a}, \mathrm{b}, \mathrm{x}}$ & $0.7^{\mathrm{a}, \mathrm{b}, \mathrm{x}}$ \\
D2 & $1.4^{\mathrm{a}, \mathrm{b}, \mathrm{x}}$ & $1.8^{\mathrm{a}, \mathrm{x}}$ & $1.4^{\mathrm{b}, \mathrm{x}}$ & $1.7^{\mathrm{a}, \mathrm{b}, \mathrm{x}}$ \\
\hline
\end{tabular}

radiolytic products are generated and in what ratios, affecting also food matrix viscosity and water mobility. Ion and free radical dispersion are lower when free water is in the frozen state. Also, free radicals tend to recombine when water in foods is frozen because they are less likely to diffuse and react with other food components (Taub et al., 1975). Storage time did not affect $a^{*}$ and $b^{*}$ values. Lightness $\left(L^{*}\right)$ was not affected by irradiation dose or temperature, but it did decrease with storage time, being lower on samples stored for 30 days after irradiation. The same behavior was observed for the saturation index, decreasing with storage. Nevertheless, Millar, Moss, and Stevenson (2000) suggested that CIELAB parameters may not be sufficiently sensitive indicators of pigment changes following irradiation. Several studies have shown that packaging atmosphere (aerobic or anaerobic) has a greater effect on meat color than does irradiation alone (Ahn, Olson, Lee, et al., 1998; Luchsinger et al., 1996; Murano et al., 1998).

It is important to remark that instrumental color on beef trimmings and patties are not comparable in this study, since color measures on beef trimmings were made exclusively in the muscle (excluding the fat) and patties were made by grinding and mixing these two components (muscle and fat); thus, differences explained by the contribution of fat to final color of patties were expected.

Irradiation dose did not significantly affect $\mathrm{L}^{*}, \mathrm{a}^{*}$ and $\mathrm{b}^{*}$ values on beef patties $(p>0.05)$ (Table 4$)$. These results agree with those reported by Murano et al. (1998), who found that the only differences between non irradiated and irradiated ( $2 \mathrm{kGy}$ ) beef patties were due to packaging atmosphere. On the other hand, Montgomery et al. (2000) reported lower $\mathrm{a}^{*}$ and $\mathrm{b}^{*}$ values and higher $\mathrm{L}^{*}$ values on beef patties irradiated with 2 kGy compared with non-irradiated samples. All color scores were significantly higher in patties made of trimmings aged for 30 days related to patties made with fresh $(1 \mathrm{~d})$ trimmings. Values of $\mathrm{L}^{*}$, $\mathrm{a}^{*}$ and saturation indexes decreased significantly during the 180 days of storage while $b^{*}$ values remained unchanged.

Table 6

Consumer acceptability mean values for patties made of fresh (1 d) and aged (30 d) trimmings. Within columns, treatment means with common letters (a,b) are not significantly different $(P>0.05) . n s$; within rows, treatment means with common letters $(\mathrm{x}, \mathrm{y})$ are not significantly different $(P>0.05)$.ns.

\begin{tabular}{lllll}
\hline & \multicolumn{2}{l}{ Consumer acceptability } \\
\cline { 2 - 5 } & \multicolumn{2}{l}{1 day aged trimming } & \multicolumn{2}{l}{30 day aged trimming } \\
\hline Dose & $1 \mathrm{~d}$ & $180 \mathrm{~d}$ & $1 \mathrm{~d}$ & $180 \mathrm{~d}$ \\
$\mathrm{Ni}$ & $6.6^{\mathrm{a}, \mathrm{x}, \mathrm{y}}$ & $6.0^{\mathrm{a}, \mathrm{y}}$ & $7.0^{\mathrm{a}, \mathrm{x}}$ & $6.7^{\mathrm{a}, \mathrm{x}, \mathrm{y}}$ \\
$\mathrm{D} 1$ & $6.6^{\mathrm{a}, \mathrm{x}}$ & $5.8^{\mathrm{a}, \mathrm{y}}$ & $6.1^{\mathrm{b}, \mathrm{x}, \mathrm{y}}$ & $6.2^{\mathrm{a}, \mathrm{x}, \mathrm{y}}$ \\
$\mathrm{D} 2$ & $6.2^{\mathrm{a}, \mathrm{x}, \mathrm{y}}$ & $5.5^{\mathrm{a}, \mathrm{y}}$ & $6.0^{\mathrm{b}, \mathrm{x}, \mathrm{y}}$ & $6.5^{\mathrm{a}, \mathrm{x}}$ \\
\hline
\end{tabular}


Table 7

Detection of L. monocytogenes and E. coli 0157:H7 by PCR “BAX® System method after irradiation treatment (3 kGy): $(-)$ not detectable $(+)$ presence.

\begin{tabular}{|c|c|c|c|}
\hline \multicolumn{2}{|l|}{ L. monocytogenes } & \multicolumn{2}{|l|}{ E. coli 0157:H7 } \\
\hline Inoculum (log cfu/g) & Presence & Inoculum (log cfu/g) & Presence \\
\hline Control & - & Control & - \\
\hline 1.52 & - & 1.32 & - \\
\hline 2.52 & - & 2.32 & - \\
\hline 3.52 & + & 3.32 & - \\
\hline 4.52 & + & 4.32 & - \\
\hline 5.52 & + & 5.32 & + \\
\hline
\end{tabular}

\subsubsection{Sensory evaluation}

Off-flavor intensity of patties was the only parameter where judges detected differences with increasing irradiation dose. Table 5 shows off-flavor intensity of patties made of irradiated and non-irradiated fresh $(1 \mathrm{~d})$ and $30 \mathrm{~d}$ stored trimmings. The other sensory attributes assayed showed no significant changes due to irradiation treatment or storage time of trimmings and patties. Their values, in a 0 to 10 continuous scale ranged as follows: odor intensity [ 5 to 6 ]; off odor intensity [0.3 to 1.4]; initial tenderness [4.2 to 5.9]; final tenderness [4.7 to 5.8]; initial juiciness [4.2 to 5.7]; final juiciness [3.9 to 5.7] and flavor intensity [5.0 to 6.2 ]

Table 5 shows that off flavor scores of patties made of aged irradiated trimmings did not differ $(P>0.05)$ from patties made of fresh $(1 \mathrm{~d})$ irradiated trimmings. Patties made of trimmings irradiated at D2 significantly differed from patties made of non-irradiated trimmings for both fresh and aged ones. Nevertheless, values obtained for off flavor were all below 2 in a 0 to 10 scale and they experienced no changes during the $180 \mathrm{~d}$ storage period at freezing temperature. Giroux et al. (2001) with the use of a trained panel, concluded that there was no significant difference in odor and taste between irradiated ( $4 \mathrm{kGy}$ ) and non-irradiated ground beef patties ( $23 \%$ fat) during 7 days of storage at $4{ }^{\circ} \mathrm{C}$. Sommers et al. (2004) performed a study evaluating frozen ground beef patties (15\% fat) irradiated and non-irradiated at doses of 1.35 and $3 \mathrm{kGy}$. Irradiation had no significant impact on the ratings of any of the sensory attributes either at $1 \mathrm{~d}$ or after 6 months of storage. Similar results were found by Zienkewicz and Penner (2004) with 25\% fat ground beef.

Consumer acceptability is one of the tools used to predict market product success and the likelihood of rejection of consumers if this is the case. Table 6 shows acceptability results for patties made of fresh irradiated and non-irradiated trimmings at 1 and $180 \mathrm{~d}$ of frozen storage.

It was observed that irradiated patties did not differ from nonirradiated ones $(P>0.05)$ for both 1 and $180 \mathrm{~d}$ storage times. Irradiated patties $180 \mathrm{~d}$ old showed less acceptability $(P<0.05)$ than $1 \mathrm{~d}$ old patties though these values were proximate to the original ones.

Results from judges (trained panelists) and consumers indicate that there are no sensory differences between patties produced from fresh (1 d) or $30 \mathrm{~d}$ stored irradiated trimmings at 2 or $5 \mathrm{kGy}$, suggesting

Counts of $E$. coli O157:H7 - low inoculum

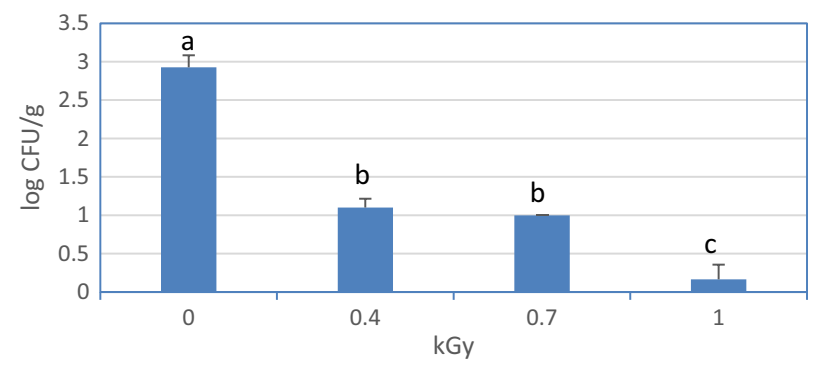

Fig. 3. E. coli $0157: \mathrm{H} 7$ counts* (log cfu/g) of irradiated trimmings previously inoculated with the target bacteria at low concentration. $(n=6){ }^{*}$ counted as mesophilic aerobic.
Counts of E. coli 0157:H7 - high inoculum

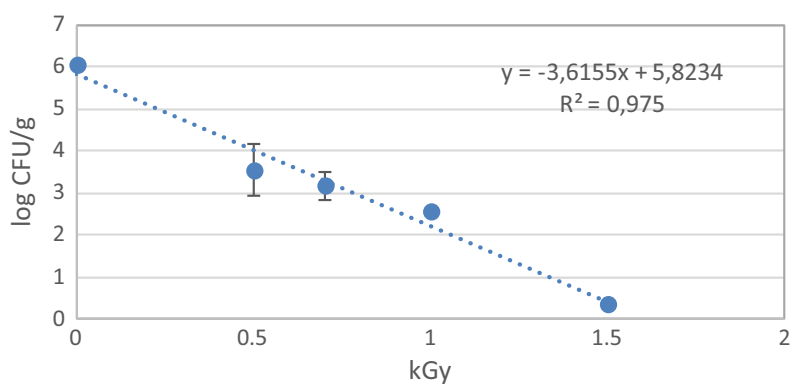

Fig. 4. E. coli $0157: \mathrm{H} 7$ counts* (log cfu/g) of irradiated trimmings previously inoculated with the target bacteria at high concentration. $(n=6)$. Different letters in bars mean that counts are significantly different $(P<0.05) .{ }^{*}$ counted as mesophilic aerobic.

that it is possible to commercialize irradiated trimmings as such to markets that require 30 days for transport and beef patties for up to a $180 \mathrm{~d}$ period $(p>0.05)$ taking into account only sensory results.

\subsection{Effect on pathogenic cells}

\subsubsection{Effectiveness of selected dose}

In order to determine the effectiveness of the selected dose in terms of pathogenic markers, $3 \mathrm{kGy}$ was chosen as target dose because it was the upper end of the range of absorbed doses assayed for D1 with the trimmings destined for patty manufacture. In addition in sensory evaluation trials, the $5 \mathrm{kGy}$ dose (D2) caused barely higher scores of off flavor intensity.

Irradiation close to $3 \mathrm{kGy}$ reduced below detectable levels a $2.5 \mathrm{log}$ cfu/g of L. monocytogenes and $4.3 \mathrm{log}$ cfu/g of E. coli 0157:H7 (Table 7). Higher resistance of $L$. monocytogenes was expected because gram positive bacteria are often found to be more resistant than gram negative bacteria in foods (Farkas, 2001). In agreement with our findings, Gumus et al. (2008) investigated the irradiation effect on inoculated meatballs and demonstrated that a dose of $3.2 \mathrm{kGy}$ reduced counts of $4.3 \mathrm{log} \mathrm{cfu} / \mathrm{g}$ of E. coli 0157:H7. Samelis, Kakouri, Savvaidis, Rigankos, and Kontominas (2005) studied the use of ionizing radiation to control Listeria spp. and E. coli 0157:H7 on frozen meat trimmings and showed that a dose of $2 \mathrm{kGy}$ caused a $1.6 \mathrm{log} \mathrm{cfu} / \mathrm{g}$ reduction for an initial count of $6.0 \log$ Listeria spp. whereas the reduction at a $4 \mathrm{kGy}$ dose was $2.5 \mathrm{log}$ $\mathrm{cfu} / \mathrm{g}$. For E. coli O157:H7 the reductions at 2 and $4 \mathrm{kGy}$ were 2 and $>4.5$ $\log \mathrm{cfu} / \mathrm{g}$ respectively for an initial count of $5.5 \log \mathrm{cfu} / \mathrm{g}$.

\subsubsection{Lethality curves}

Initial counts of both E. coli 0157:H7 and L. monocytogenes in inoculated trimmings destined to be irradiated at different doses can be seen on Figs. 3 to 6. Their reductions as a consequence of the irradiation process can be easily estimated from experiments with high inoculums. For E. coli 0157:H7 irradiation doses of 0.5, 0.7, 1.0 and $1.5 \mathrm{kGy}$ provoked

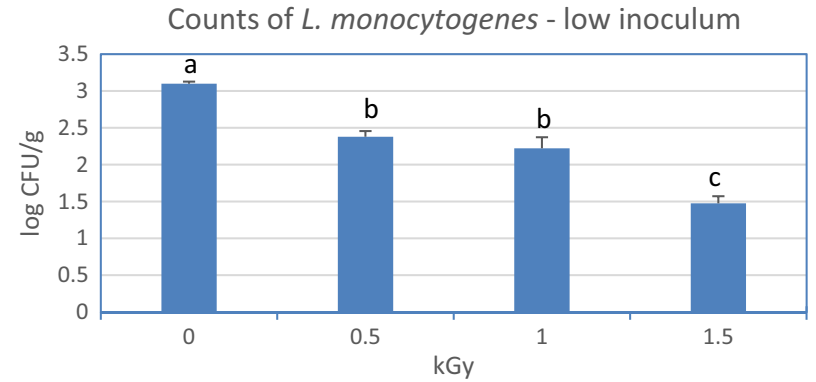

Fig. 5. L. monocytogenes counts* (log cfu/g) of irradiated trimmings previously inoculated with the target bacteria at low concentration. $(n=6){ }^{*}$ counted as mesophilic aerobic 
Counts of L. monocytogenes - high inoculum

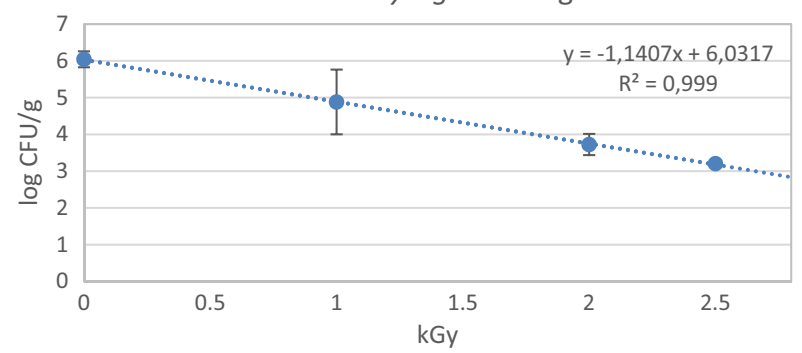

Fig. 6. L. monocytogenes counts* $(\log \mathrm{cfu} / \mathrm{g})$ of irradiated trimmings previously inoculated with the target bacteria at high concentration. $(n=6)$. Different letters in bars mean that counts are significantly different $(P<0.05) .{ }^{*}$ counted as mesophilic aerobic.

reductions of: $2.6 \pm 0.5 ; 3.3 \pm 0.3 ; 3.5 \pm 0.0$ and $5.75 \pm 0.03 \log \mathrm{cfu} / \mathrm{g}$, respectively. Decimal reduction value coefficient ( $D_{10}$ value) was estimated from lethality curves adjusted by linear regression (least square means) as 0.28 ( $\left.R^{2} 0.98\right)$. For $L$. monocytogenes irradiation doses of 1,2 and $2.5 \mathrm{kGy}$ produced reductions of $1.2 \pm 0.4 ; 2.32 \pm 0.04$ and $2.8 \pm$ $0.1 \mathrm{log} \mathrm{cfu} / \mathrm{g}$, respectively. Estimated $D_{10}$ value was $0.71\left(R^{2} 0.99\right)$. Both $D_{10}$ values are related to the range assessed for high inoculums experiments, where fit to linear approach seemed reasonable in the conditions of this experiment.

As it was told, reductions of L. monocytogenes obtained in trimmings samples are lower than those obtained for E. coli 0157:H7 for both high and low inoculums assayed. This is in agreement with findings regarding not only irradiation technology (Farkas, 2001) but also other nonthermal processes such as high hydrostatic pressure processing (Hereu et al., 2012). For the series of experiments carried out at low inoculums, additional reduction values could only be estimated for L. monocytogenes: $0.72 \pm 0.05$ and $1.62 \pm 0.07 \log \mathrm{cfu} / \mathrm{g}$, respectively for 0.5 and $1.5 \mathrm{kGy}$. Reduction values obtained for $1.0 \mathrm{kGy}$ were similar to those of high inoculum experiments. For E. coli 0157:H7, count values were often below or proximate to the detection limit of the technique $\left(10^{1} \mathrm{cfu} / \mathrm{g}\right)$.

The values obtained in this work are similar to those found by Molins (2001), although they were higher than reduction values of Sommers et al. (2004). This fact could be explained by differences between food matrices in composition (fat to protein ration, presence of antioxidants, $\mathrm{pH}$, water activity) and irradiation equipment designs.

Technological enhancement of food quality, safety and security are of paramount importance in this age. The global food system makes a significant contribution to climate changing greenhouse gas emissions with all the stages in the supply chain, from agricultural production through processing, distribution, retailing, home food preparation and waste, playing a part. This has been estimated in up to $28 \%$ for developed countries (Garnett, 2011). The use of thermal or non-thermal preservation technologies contributes to improve the unit efficiency of food production, enhancing extending terms for food distribution (and accessibility) while reducing waste at the same time. Technology may play a key role to address the problems faced reducing environmental impacts and increasing supply. Waste should be minimized through better inventory management, and through approaches that either extend the shelf life of foods maintaining its quality (Garnett, 2013; WRAP, 2012).

\section{Conclusions}

Previous and current studies show that irradiation treatments are useful to diminish regular microflora normally present in raw meat or trimmings. This study has been carried out using beef trimmings, representing a huge share of the world trade market of meat destined for formulation of burgers or patties. The joint indicators studied both from the quality attributes $(\mathrm{pH}$, color, TBA, sensory analysis, coliforms and mesophilic counts) and from the safety points of view (pathogenic cells), support the role of irradiation as a useful processing tool to guaranty food safety of trimmings and patties slightly altering its physicochemical and sensory properties. Provided that moderate gamma irradiation doses up to $2.5 \mathrm{kGy}$ were used, at least reductions of $2 \mathrm{log}$ $\mathrm{cfu} / \mathrm{g}$ of L. monocytogenes and $5 \mathrm{log} \mathrm{cfu} / \mathrm{g}$ of E. coli 0157:H7 are achieved as deducted from lethality curves. It seems reasonable to suppose that irradiation can be successfully employed to achieve the safety of frozen trimmings when the initial load of pathogenic bacteria is not extremely high.

\section{References}

Ahn, D. U., \& Nam, K. C. (2004). Effects of ascorbic acid and antioxidants on color, lipid oxidation and volatiles of irradiated ground beef. Radiation Physics and Chemistry, 71, 149-154.

Ahn, D. U., Olson, D.G., Jo, C., Chen, X., Wu, C., \& Lee, J. I. (1998a). Effect of muscle type packaging and irradiation on lipid oxidation volatile production and color in raw pork patties. Meat Science, 49(1), 27-39.

Ahn, D. U., Olson, D.G., Lee, J. I., Jo, C., Wu, C., \& Chen, S. (1998b). Packaging and irradiation effects on lipid oxidation and volatiles in pork patties. Journal of Food Science, 63(1), 15-19.

AMSA (1995). Research guidelines for cookery, sensory evaluation and instrumental tenderness measurements of fresh meat. American Meat Science Association.

AMSA (2012). Meat color measurement guidelines (2nd ed.). American Meat Science Association.

AOCS (2009). Thiobarbituric acid value. AOCS Official Method Cd 19-90, Direct method, (Reapproved 2009).

Brewer, M. S. (2004). Irradiation effects on meat color-A review. Meat Science, 68, 1-17.

Brito, G. (2005, setiembre 28-30). Diferenciación y valorización de las carnes bovinas y ovinas del Uruguay a partir de su caracterización nutricional y su influencia en la salud humana y la conservación del producto. INNOVA (Retrieved from http://www. innova-uy.info/docs/presentaciones/20050929/2005DOCGustavoBrito.pdf).

Caprioli, A., Morabito, S., Brugere, H., \& Oswald, E. (2005). Enterohaemorrhagic Escherichia coli: Emerging issues on virulence and modes of transmission. Veterinary Research, 36 289-311.

CDC (2011). Vital signs: incidence and trends of infection with pathogens transmitted commonly through food-Foodborne diseases active surveillance network, 10 U.S. sites, 1996-2010. Morbidity and Mortality Weekly Report, 60(22), 749-755.

Chouliara, I., Samelis, J., Kakouri, A., Badeka, A., Savvaidis, I. N., Riganakos, K. \& Kontominas, M. G. (2006). Effect of irradiation of frozen meat/fat trimmings on microbiological and physicochemical quality attributes of dry fermented sausages. Meat Science, 74, 303-311.

EFSA (2007). Scientific opinion of the panel on biological hazards on a request from EFSA on monitoring of verotoxigenic Escherichia coli. EFSA Journal, 579, 1-61.

EFSA (2011). Shiga toxin/verotoxin-producing Escherichia coli in humans, food and animals in the EU/EEA, with special reference to the German outbreak strain STEC 0104. In J. Takkinen, M. Struelens, T. Niskanen, P. Makela, V. Rizzi, A. Caprioli, \& F. Scheutz (Eds.), Microbiology of Shiga toxin/verotoxin producing Escherichia coli (pp. 2) (Stockholm).

EFSA (2012). The European Union summary report on trends and sources of zoonoses, zoonotic agents and food-borne outbreaks in the European Union in 2010. EFSA Journal, 10(3), 2597-3039.

Farkas, J. (2001). Irradiation of minimally processed foods. Food irradiation: Principles and applications (pp. 273-290). New York: Wiley.

FDA (2012). Irradiation in the production, processing and handling of food. Federal Register, 77 ( $\mathrm{n}^{\circ} 231.21$ CFR 179).

Fu, A. H. Sebranek, J. G. \& Murano, E. A. (1995). Survival of Listeria monocytogenes, Yersinia enterocolitica and Escherichia coli 0157:H7 and quality changes after irradiation of beef steaks and ground beef. Journal of Food Science, 60, 972-977.

Garnett, T. (2011). Where are the best opportunities for reducing greenhouse gas emmissions in the food system (including the food chain). Food Policy, 36, S23-S32.

Garnett, T. (2013). Conference on "Future and health" Symposium I: Sustainability and food security. Food Sustainability: problems, perspectives and solutions. Proceedings of the Nutrition Society, 72, 29-39.

Giroux, M., Ouattara, B., Yefsah, R., Smoragiewicz, W., Saucier, L., \& Lacroix, M. (2001) Combined effect of ascorbic acid and gamma irradiation on microbial and sensorial characteristics of beef patties during refrigerated storage. Journal of Agriculture and Food Chemistry, 49, 919-925.

Gumus, T., Demirci, A., Velioglu, H. M., Velioglu, S. D., Yilmaz, I., \& Sagdic, O. (2008). Application of gamma irradiation for inactivation of three pathogenic bacteria inoculated into meatballs. Radiation Physics and Chemistry, 77, 1093-1096.

Hereu, A., Dalgaard, P., Garriga, M., Aymerich, T., \& Bover-Cid, S. (2012). Modeling the high pressure inactivation kinetics of Listeria monocytogenes on RTE cooked meat products. Innovative Food Science and Emerging Technologies, 16, 305-315.

ICGFI (1996). Irradiation of red meat: A compilation of technical data for its authorization and control. Vienna: Joint FAO/IAEA Division of Nuclear Techniques in Food and Agriculture.

ILSI (2005). Research Foundation/Risk Science Institute, E' expert panel on Listeria monocytogenes in foods.

ISO (1996). Microbiology of food and animal feeding stuffs: Horizontal method for the detection and enumeration of Listeria monocytogenes. Part 1: Detection methodISO 11290-1:1996 Geneva, Switzerland: International Organization for Standardization. 
ISO (2002). Practice for use of a polymethylmethacrylate dosimetry system. ISO/ASTM 51276:2002. Geneva, Switzerland: International Organization for Standardization.

ISO (2004). Practice for use of the alanine-EPR dosimetry system. ISO/ASTM 51607:2004. Geneva, Switzerland: International Organization for Standardization.

ISO (2007). Sensory analysis: General guidance for the design of test rooms. ISO 8589:2007. Geneva, Switzerland: International Organization for Standardization.

Jofré, A., Aymerich, T., Grèbol, N., \& Garriga, M. (2009). Efficiency of high hydrostatic pressure at $600 \mathrm{MPa}$ against food-borne microorganisms by challenge tests on convenience meat products. Food Science and Technology, 42, 924-928.

Karadag, A., \& Günes, G. (2007). The effects of gamma irradiation in the quality of ready to cook meatballs. Turkish Journal of Veterinary and Animal Science, 32, 269-274.

Law, D. (2000). Virulence factors of Escherichia coli 0157 and other Shiga toxinproducing E. coli. Journal of Applied Microbiology, 88, 729-745.

Lescano, G., Narvaiz, P., Kairiyama, E., \& Kaupert, N. (1991). Effect of chicken breast irradiation on microbiological, chemical and organoleptic quality. Lebensmitta Wissenund Technology, 24, 130-134

Lorenz, G., Stern, D. J., Flath, R. A., Haddon, W. F., Tillin, S. J., \& Teranishi, R. (1983). Identification of sheep liver volatiles. Journal of Agriculture and Food Chemistry, 31, 1052-1057.

Luchsinger, S. E., Kropf, D. H., Garcia-Zepeda, C. M., Hunt, M. C., Marsden, J., Rubio, E. J., Kastner, C. L., Kuecker, W. G., \& Mata, T. (1996). Color and oxidative rancidity of gamma and electron beam irradiated boneless pork chops. Journal of Food Science, 1000-1005.

Lycometros, C., \& Brown, W. D. (1973). Effects of gamma irradiation on myoglobin. Journal of Food Science, 38(6), 971-977.

Millar, S. J., Moss, B. W., \& Stevenson, M. H. (2000). The effect of ionizing radiation on the color of beef, pork and lamb. Meat Science, 55, 349-360.

Molins, R. A. (2001). Irradiación de carnes y aves de corral. In R. A. Molins (Ed.), Irradiación de alimentos: Principios y aplicaciones (pp. 469). Hoboken, NJ: John Wiley \& Sons.

Momtaz, H., Dehkordi, F. S., Rahimi, E., Ezadi, H., \& Arab, R. (2013). Incidence of Shiga toxin-producing Escherichia coli serogroups in ruminant's meat. Meat Science, 95, 381-388.

Momtaz, H., Farzan, R., Rahimi, E., Safarpoor Dehkordi, F., \& Souod, N. (2012). Molecular characterization of Shiga toxin-producing Escherichia coli isolated from rumiant and donkey raw milk samples and traditional dairy products in Iran. Scientific World Journal http://www.hindawi.com/journals/tswj/2012/231342/.

Montgomery, J. L., Parrish, J. R., \& Olson, D.G. (2000). Irradiation and storage effects on aroma and color of raw beef patties in anaerobic or aerobic packaging. Journal of Muscle Foods, 11(9), 19-33.

Murano, P.S., Murano, E. A., \& Olson, D.G. (1998). Irradiated ground beef: Sensory and quality changes during storage under various packaging conditions. Journal of Food Science, 63, 548-551.

Nam, K. C., \& Ahn, D. U. (2003). Effects of ascorbic acid and antioxidants on the color of irradiated ground beef. Journal of Food Science, 68, 1686-1690.
Nanke, K. E., Sebranek, J. G., \& Olson, D.G. (1999). Color characteristics of irradiated aerobically packaged pork, beef, and turkey. Journal of Food Science, 64, 272-278.

Ojo, O. E., Ajuwape, A., Otesile, E., Owoade, A., Oyekunle, M., \& Adestosoye, A. I. (2010). Potentially zoonotic shiga toxin-producing Escherichia coli serogroups in the faeces and meat of food-producing animals in Ibadan, Nigeria. International Journal of Food Microbiology, 142, 214-221.

Olson, D.G. (1998a). Irradiation of food: Scientific status summary. Food Technology, $52(1), 56-62$.

Olson, D.G. (1998b). Irradiation processing. In E. Murano (Ed.), Food irradiation-A sourcebook. Meat and poultry irradiation short course. (pp. 3-27). Ames, IA: Iowa State University Press.

Samelis, J., Kakouri, A., Savvaidis, I. N., Rigankos, K., \& Kontominas, M. G. (2005). Use of ionizing radiation doses of 2 and $4 \mathrm{k} \mathrm{Gy}$ to control Listeria spp. and Escherichia coli 0157:H7 on frozen meat trimmings used for dry fermented sausage production. Meat Science, 70, 189-195.

Shahidi, F. (1994). Flavor of meat and meat products-An overview. In F. Shahidi (Ed.), Flavor of meat and meat products (pp. 1-3). London: Blackie Academic and Professional.

Sommers, C. H., Keser, N., Fan, X. T., Wallace, F. M., Novak, J. S., \& Handel, A. P. (2004). Irradiation of ready to eat meats: Eliminating Listeria monocytogenes while maintaining product quality. Irradiation of Food and Packaging: Recent developmentsACS Symposium Series, 875. (pp. 77-89), 77-89.

Talon, R., Lebert, I., Lebert, A., Leroy, S., Garriga, M., \& Aymerich, T. (2007). Traditional dry fermented sausages produced in small-scale processing units in Mediterranean countries and Slovakia. 1: Microbial ecosystems of processing environments. Meat Science, $77,570-579$.

Taub, I. A., Karielian, R. A., Halliday, J. W., Walker, J. E., Angeline, P., \& Merritt, C. (1975). Factors affecting radiolytic effects of food. Radiation Physics and Chemistry, 14, 639-653.

Thakur, B. R., \& Singh, R. K. (1994). Food irradiation. Chemistry and applications. Food Reviews International, 10(4), 437-473.

Thayer, D. W., Boyd, G., Fox, J. B., Lakritz, L., \& Hampson, J. W. (1995). Variations in radiation sensitivity of foodborne pathogens associated with meat. Journal of Food Science, 60(1), 63-67.

Todd, S. D., \& Notermans, S. (2011). Surveillance of listeriosis and its causative pathogen, Listeria monocytogenes. Food Control, 22, 1484-1490.

Warriner, K., \& Namvar, A. (2009). What is the hysteria with Listeria? Trends in Food Science E' Technology, 20(6-7), 245-254.

WRAP (2012). Courtauld commitment 2 voluntary agreement 2010-2-12 signatory case studies and quotes. Waste Resources Action Programme. London: Defra.

Zienkewicz, L. S. H., \& Penner, K. P. (2004). Consumer's perceptions of irradiated ground beef after education and product exposure. Food Protection Trends, 24, 740-745. 